\title{
Fertility and its relationship with sociocultural factors in Kuwaiti society
}

Y.Y. Al-Kandari ${ }^{1}$

$$
\begin{aligned}
& \text { الخُصوبة وعالاقتها بالعوامل الاجتماعية والثقافية في الجتمع الكويتي } \\
& \text { يعتوب يوسف الكندري }
\end{aligned}
$$

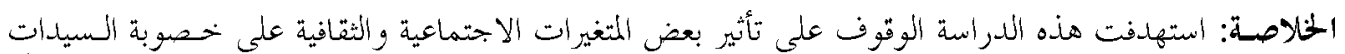

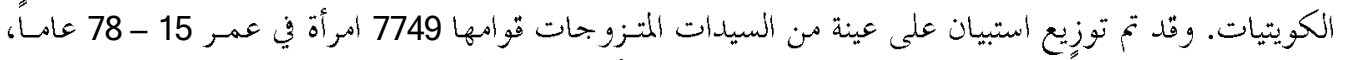

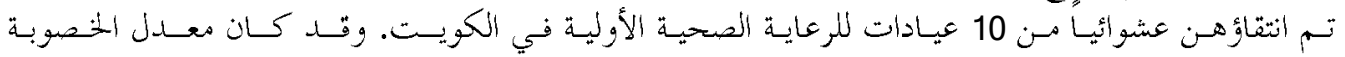

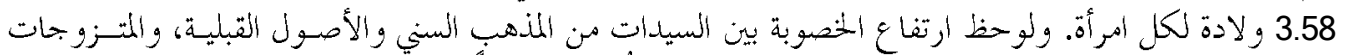

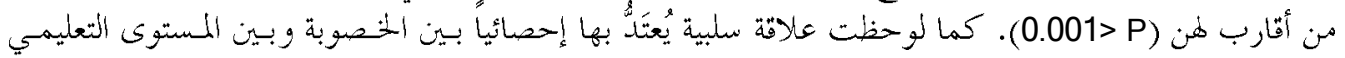

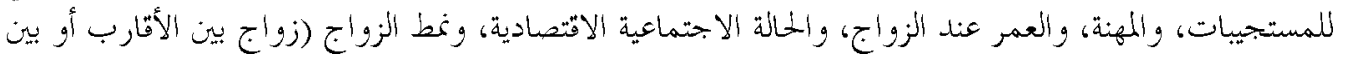

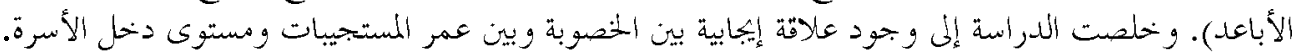

ABSTRACT The aim of this study was to examine the effect of some sociocultural variables on the fertility of Kuwaiti women. A questionnaire was administered to a sample of 7749 married women (aged 15-78 years) selected randomly from 10 primary health care clinics in Kuwait. The fertility rate was 3.58 live births per woman. Fertility was higher among Sunni Muslim women, those of Bedouin ethnicity, and those in a consanguineous marriage $(P<0.001)$. There was a significant negative relationship between fertility and respondents' educational level, occupation, age at marriage, socioeconomic status and type of marriage (consanguineous or not). There was a positive relationship between fertility and the respondents' age and the family income.

\section{Fécondité et facteurs socioculturels dans la société koweïtienne}

RÉSUMÉ Cette étude avait pour objectif d'analyser l'effet de certaines variables socioculturelles sur la fécondité de la femme koweïtienne. Un questionnaire a été administré à un échantillon de 7749 femmes mariées, âgées de 15 à 78 ans, sélectionnées au hasard parmi les patientes de 10 consultations de soins primaires koweïtiennes. Le taux de fécondité était de 3,58 naissances/femme. Le taux de fécondité le plus élevé a été enregistré chez les Musulmanes sunnites, les femmes d'origine bédouine et celles ayant contracté un mariage consanguin $(p<0,001)$. II est apparu une relation négative significative entre, d'une part, la fécondité et, d'autre part, le degré d'instruction, la profession, l'âge au mariage, le statut socio-économique et le type de mariage (consanguin ou non) des enquêtées. II a été constaté une relation positive entre cette fécondité et l'âge des enquêtées ainsi que le niveau du revenu familial.

${ }^{1}$ College of Social Science, Kuwait University, Kuwait (Correspondence to Y.Y. Al-Kandari: Yabdullah@kuc01. kuniv.edu.kw). 


\section{Introduction}

The number of children per household is decreasing in Kuwait. In 1970 the birth rate was about $45 / 1000$ population and the total fertility rate was about 7 . In 1987 , the total fertility rate had dropped to 4.4 , with 34 births/1000 population [1].

Several factors have been associated with this decline in the fertility in the $\mathrm{Ku}-$ waiti society. One such is the factor in the age at marriage among Kuwaitis, especially among females. For example, the age at marriage was estimated to be 22.4 years for Kuwaiti females in 1985 versus 20.9 years in 1975 [1]. Another factor that can affect the fertility rate and age at marriage is female education. Kohli and Al-Omaim found that illiterate women at marriage were younger than university educated females by about 5 years [2]. They also found that there was clear evidence of declining fertility in younger Kuwaitis but not in the older age groups. Abdal found that female university students had a stronger desire to limit fertility than male students, which emphasizes the effect of education on fertility [3]. The National Health Survey of 1984/5 revealed that $39 \%$ of married women in Kuwait were using contraception [3]. Shah reviewed the data of a labour survey between 1965 and 1993 and showed that female illiteracy declined as the number of females getting a higher education and going into the work force increased [4].

Another factor reported to affect fertility is ethnicity. Al-Gallaf et al. found differences between 2 major ethnic groups in Kuwait, Bedouin and non-Bedouin, with regard to their use of contraception; $42 \%$ of the Bedouin women and $65 \%$ of the nonBedouin women were using contraceptives [5]. It has also been reported that there is a relationship between fertility and degree of religiosity, regardless of the person's Muslim sect, Sunni or Shiite [3]. Marriage type can also affect fertility. More closely related couples appear to desire more children $[6,7]$.

As a result of the declining fertility in Kuwait, the Kuwaiti government, like some other governments of the area such as Iraq (during Saddam Hussain's regime), Israel, and Cyprus, have provided incentives to Kuwaiti females in an effort to raise the fertility rates $[8]$. The Kuwaiti government provides cash child allowances (at present 50 Kuwaiti dinars per child up to a maximum of 7 children) and maternity benefits ( 2 months paid leave and another 6 months off at half salary).

It is clear that the speed of economic growth in Kuwait has had many social consequences. Family structure is one of the main social aspects that has been affected. Ideas and thoughts regarding family size, spouse selection, and fertility have changed markedly in Kuwaiti families. There are few recent studies on fertility and its relationship with other sociocultural factors in Kuwait. For this reason, the main aim of this study was to examine this relationship and to see how certain sociocultural variables act as determinants in the fertility rate in Kuwaiti society today.

This paper will try to answer the following questions: is there a significant difference in the fertility rate between Kuwaitis from Bedouin versus non-Bedouin roots? Is there a significant difference in the fertility rate between the Sunni and Shiite sects? Is there a significant difference in the fertility rate between consanguineous and nonconsanguineous couples? Is there a significant relationship between the fertility rate and some other sociocultural factors?

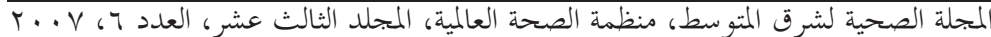




\section{Methods}

\section{Sample}

The sample was 8000 married Kuwaiti women aged 15-78 years. In order to approach this target, we distributed 8100 questionnaires to eligible women. Some were incomplete and final sample size was 7749. The sample represents about $1.7 \%$ of the total Kuwaiti female population aged 15 years and older [9]. The reason for using such wide age sample was to ensure better representatives of Kuwaiti females at age of marriage and reproduction. Another reason was to make sure of the experiences and opinions of older women concerning fertility and related variables, especially the impact of age on fertility.

The women were selected randomly from the records of 10 different primary health care (PHC) centres in Kuwait; 10 clinics were selected to ensure all ethnic groups in Kuwait were represented. Many areas in the Kuwait governorates are known to be representative of certain ethnic groups. The 10 PHC centres were selected using a cluster random sample method. These clinics are attended by individuals of all sociocultural backgrounds and ethnicities and this thus ensured that all population groups were involved in the study. No other places in Kuwait can represent all the general population. The sample was drawn from all females attending the PHC clinics for minor health problems, after they were asked if they were married or not.

\section{Study tool}

Data on the respondents' opinions about and attitudes toward fertility and the related variables were collected by a questionnaire developed locally by the author. In order to ensure validity of the questionnaire, 5 professors at the Department of Sociology and Social Work, Kuwait University reviewed it.
According to their suggestions and remarks, the questionnaire was modified. A pilot study was conducted in which the modified version of the questionnaire was given to 70 married Kuwaiti women. The results of this pilot study indicated the questionnaire was a reliable tool to assess data related to fertility among Kuwaiti women.

The questionnaire included some demographic questions. Fertility, number of births per woman, was the dependent variable. The respondents were asked directly about the number of children they had. Education was divided into 8 categories (from "read and write" and below $=1$ to doctoral degree $=8$ ). Annual family income was also divided into 8 categories. Work position had 6 categories (not working $=1$ to professional $=6$ ). Socioeconomic status (SES) was measured by using these 3 variables, i.e. annual income, educational level, and occupational position and was coded according to the Social Science Research Council [10]. The respondents were asked about their age at marriage and their kin relationship with their spouse, and the degree of the spousal relationship. Types of marriage were grouped into 9 categories: double-cousin marriage ( 2 categories), first-cousin marriage (cousins on the father's and the mother's side, 4 categories), second-cousin marriage, third-cousin marriage and non-consanguineous marriage. The respondents were asked directly about their Muslim sect, Sunni or Shiite, and their ethnicity, Bedouin and non-Bedouin.

\section{Data collection}

Data collection took about 6 months from January to June 2002. The questionnaire was distributed by 10 trained research assistants. The respondents answered the questionnaire voluntarily after an explanation of the aim of study by the research assistants. The research assistants helped any 
respondents who were illiterate to complete the questionnaire.

Because of the direct contact between research assistants and the respondents, the response rate was high $(96 \%)$. Most of the non-responders were excluded because they did not complete all parts of the questionnaire.

\section{Statistical analysis}

SPSS, version 11.0 was used for the data analysis. The data were analysed using both descriptive and inferential statistics. Descriptive statistics such as mean and standard deviation (SD) were used. To examine the differences between sect, origin, and marriage type, the Student $t$-test was used. Pearson correlation was used to assess the degree and nature of the relationship between fertility and some sociocultural variables. Finally a multivariate regression model was used to predict the outcome.

For statistical analysis purposes, type of marriage was dichotomized as consan- guineous and non-consanguineous marriage and by the degree of relation between the spouses (4 categories) beginning with the double-cousin marriage and first-cousin marriage, second-cousin marriage, thirdcousin marriage, and non-consanguineous marriage.

\section{Results}

The average fertility for the entire sample $(n=7749)$ was 3.58 (SD 2.45). Table 1 shows the difference between some sociocultural variables and fertility, namely ethnicity, type of marriage and sect. There were significant differences between all 3 variables in relation to fertility. Bedouin respondents had a higher mean fertility than non-Bedouin $[3.71(\mathrm{SD} 2.67)$ versus 3.43 (SD 2.18) respectively, $P<0.001]$. Respondents married to a relative had a higher mean fertility than those married to a non-relative [3.51 (SD 2.19) versus 3.34

\begin{tabular}{|c|c|c|c|c|}
\hline Variable & No. & $\begin{array}{l}\text { Mean no. } \\
\text { of births } \\
\text { per woman }\end{array}$ & $\begin{array}{l}\text { Standard } \\
\text { deviation }\end{array}$ & $t$-value \\
\hline \multicolumn{5}{|l|}{ Ethnicity } \\
\hline Bedouin & 4014 & 3.71 & 2.67 & $4.5^{* * *}$ \\
\hline Non-Bedouin & 2845 & 3.43 & 2.18 & \\
\hline \multicolumn{5}{|l|}{ Type of marriage } \\
\hline Consanguineous & 4009 & 3.79 & 2.62 & $-6.54^{* * *}$ \\
\hline Non-consanguineous & 3306 & 3.41 & 2.28 & \\
\hline \multicolumn{5}{|l|}{ Muslim sect } \\
\hline Sunni & 5463 & 3.64 & 2.53 & $4.37^{\star \star \star}$ \\
\hline Shiite & 1865 & 3.38 & 2.15 & \\
\hline \multicolumn{5}{|l|}{ Muslim sect } \\
\hline $\begin{array}{l}\text { Sunni (Bedouins } \\
\text { excluded) }\end{array}$ & 1591 & 3.51 & 2.19 & $4.37^{\star * *}$ \\
\hline Shiite & 1244 & 3.34 & 2.15 & \\
\hline
\end{tabular}

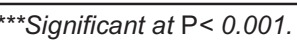


(SD 2.15) respectively, $P<0.001]$. Sunni respondents had higher mean fertility than Shiites [3.64 (SD 2.53) versus 3.38 (SD $2.15)$ respectively, $P<0.001]$.

Shiites are considered a minority in Kuwait. They show a lower mean fertility. They come mostly from non-Bedouin society while those who come from Bedouin origins are Sunni. Even when comparing Sunnis (excluding Bedouins) with Shiites (Table 1) there was also a significant difference between the 2 groups. The nonBedouin Sunni respondents had a higher mean fertility rate than the Shiites [3.51 (SD 2.19 ) versus 3.34 (SD 2.15) respectively, $P<0.001]$.

Table 2 illustrates this correlation between the fertility rate and selected sociocultural variables. The data show that there were significant relationships between fertility and all of the selected sociocultural variables. There was a negative relationship between fertility and the respondents' educational level, job position, age at marriage, SES and type of marriage $(P<0.01)$. On the other hand, there was a positive relationship between fertility and the respondents' age and family income $(P<0.01)$.

\begin{tabular}{lc}
\hline $\begin{array}{l}\text { Table } 2 \text { Correlation of fertility of the sample } \\
\text { of women in Kuwait with sociocultural } \\
\text { variables }\end{array}$ \\
\hline Variable & \multicolumn{1}{c}{$\boldsymbol{r}$} \\
\hline Educational level & $-0.40^{* *}$ \\
Occupation & $-0.18^{* *}$ \\
Family income & $0.10^{* *}$ \\
Age at marriage & $-0.30^{* *}$ \\
Age & $0.65^{* *}$ \\
Socioeconomic status & $-0.28^{* *}$ \\
Type of marriage & $-0.10^{* *}$ \\
\hline **Significant at $\mathrm{P}<0.01$. &
\end{tabular}

To predict the effect of selected sociocultural variables on fertility, multivariate regression was used. Independent variables were respondents' age, education level, age at marriage, sect, ethnicity, SES, and marriage type (Table 3). The analysis shows that Shiite respondents would be expected to have 0.17 fewer children than Sunnis, and non-Bedouin respondents 0.33 fewer children than the Bedouins. In addition, high education level, high age at marriage, and lesser degree of consanguinity of the respondents predicted lower fertility. An increase of $1 \mathrm{SD}$ in the educational level of the respondents was associated with a $0.10 \mathrm{SD}$ decrease in the family size. As expected also, an increase in $1 \mathrm{SD}$ in the respondents' age at marriage was associated with a $0.26 \mathrm{SD}$ decrease in the number of children. Also, an increase in $1 \mathrm{SD}$ in the marriage type was associated with $0.02 \mathrm{SD}$ decrease in the family size. In contrast, high family income of the respondents predicted an increase in the number of children. A 1 SD increase in the family income of the respondents was associated with a 0.10 SD increase in the number of children. As

\begin{tabular}{|c|c|c|c|}
\hline Variable & B & $\beta$ & $t$-value \\
\hline Age & 0.14 & 0.60 & $60.57^{*}$ \\
\hline Education & -0.14 & -0.10 & $-7.15^{*}$ \\
\hline Age at marriage & -0.15 & -0.26 & $-27.40^{*}$ \\
\hline Sect & -0.17 & -0.03 & $-3.10^{* * *}$ \\
\hline Ethnicity & -0.33 & -0.07 & $-6.73^{* * *}$ \\
\hline Family income & 0.12 & 0.10 & $3.90^{*}$ \\
\hline Marriage type & -0.13 & -0.02 & $-2.10^{* *}$ \\
\hline
\end{tabular}


expected, the high age of the respondents predicted higher family size.

\section{Discussion}

Fertility is affected by sociocultural changes. In some societies, a decline in fertility has been related to a decline in polygyny [11]. In others there is a connection between lower fertility and the raising of the age at marriage [12]. Current ways of thinking and attitudes regarding fertility are a direct result of modernization.

The current study confirms the general decline in the fertility rate in Kuwait over time. The fertility rate was 3.58 , while in 1970, it was 7.0 and in 1987 it was reported to be $4.4[1]$. One of the most probable reasons for this is the increase in the age at marriage for both male and female Kuwaitis. Recent studies show that the perceived ideal average age of marriage is 25.7 years for males and 21.4 years for females [6,7]. In the past, these ages for getting married were considered to be "very old" for both males and females. The ideal age and time for getting married for both males and females appears to be almost immediately upon graduation from university for females and around 2 to 3 years after graduation for males. Modernization has played a major role in changing the attitudes regarding marriage and the age at marriage.

Fertility is affected by many different cultural, socioeconomic, and environmental factors, as seen in many different cultures and societies. For example, fertility is influenced by society type, such as urban and non-urban society $[13,14]$. Education and occupation, especially for women, are other important factors that influence fertility. Educated and employed women are more likely to use contraception than those who have little education and who are not employed [15].
The changing attitudes regarding the age at marriage are related to education for both genders but especially for females. University education and also higher education for females is increasing in Kuwait. Jobs have also become an important aspect of women's lives. As stated by Shah, female illiteracy has declined and the proportion of females with a degree in higher education and involved in the labour force has increased [4].

Another factor affecting age at marriage is that both males and females are less financially dependent on their families and extended families compared with the past. For this reason, education and work have become more important for females. Female awareness and dependency on herself are major changes in the family structure in Kuwaiti society and this has led to an increase in the age at marriage. For a man, dependency on himself and establishing himself financially is important before marriage and this can usually only be completed after graduation from university. These changes in the family structure have thus affected the fertility rate.

It has been shown that there is an inverse relationship between a household's socioeconomic status and its fertility level [16]. In this study, fertility was negatively associated with the socioeconomic status of the respondents. On the other hand, the data also showed that there was a positive relationship between fertility and family income. This is expected since the government of Kuwait now encourages couples to have children and provides cash child allowances for each family; around US\$ 160 per month per child, which increases the family income. However, the general socioeconomic status was negatively correlated with fertility, although family income was one dimension of the socioeconomic measure.

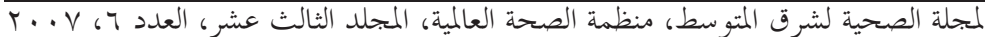


Ethnicity is another factor affecting fertility. It is reported in the United States, for example, that the differences in fertility rates for American Indians, Hispanics, and Asian or Pacific Island Americans were considerable [17]. The findings in this study show that fertility was affected by ethnicity. The respondents who came originally from Bedouin society had a higher fertility rate compared with non-Bedouins. Children, especially males, in Bedouin life and family structure are very important. They are called ezwa or sanad which mean "supporter." Bedouins have now all settled in cities in modern Kuwait, but their ideas about the importance of children in the family still differ from non-Bedouins. This may explain why Bedouins have a higher fertility rate. Al-Gallaf et al. in 1995 reported that there was a significant difference in the level of contraception use between Bedouin and non-Bedouin women [5]. They found that the use of a contraceptive method was $42 \%$ for Bedouin women and $65 \%$ for nonBedouin women.

There are differences in results of studies about the fertility of minorities compared with the whole population. Some studies have concluded that minorities have a higher fertility rate and others showed the opposite [18,19]. Muslim Shiites comprise around $20 \%$ to $30 \%$ of the total popula- tion of Kuwaiti nationals. The data in the current study show that this group had a lower fertility rate than the whole Kuwaiti population, even when ethnicity was controlled for. More studies are needed for a clear explanation of the low rate of fertility in this group.

Consanguinity plays a major role in fertility. It has been reported that consanguinity is related to high fertility rates in many different cultures [20]. In contrast, another study showed that women in consanguineous marriages had a lower mean number of conceptions [21]. The data in the current study show that non-consanguineous couples had lower fertility rates than related couples. There are 2 possible explanations for this: first, most consanguineous marriages occur among the Bedouins for whom children are very important; second, the age of marriage in consanguineous marriages is earlier than in non-consanguineous marriages. This has been also reported in other recent studies $[6,7]$.

It would appear that some traditional attitudes that affect fertility are in decline in Kuwait as a result of modernity. Many sociocultural factors play a major role in determining family size. This suggests there may be an increase in some subgroups of the population compared with others.

\section{References}

1. Kohli K, Al-Omaim MH. Fertility in Kuwait: 1970-1985. Genus, 1993, 49(3-4):55-69.

2. Kohli KL, Al-Omaim M. Fertility levels, trends and differentials in Kuwait. Journal of biosocial science, 1986, 18(2):179_ 208.

3. Abdal Y. Determinants of fertility expectations in Kuwait: A pilot study regarding reproduction behavior of the students at Kuwait University. Journal of the Gulf and Arabian Peninsula studies, 2001, 110(29):45-68.

4. Shah NM. Structural changes in the receiving country and future labor migration-the case of Kuwait. International migration review, 1995, 29(4):1-22.

5. Al-Gallaf $\mathrm{K}$ et al. Ethnic differences in contraceptive use in Kuwait: A clinic-based 
study. Social science \& medicine, 1995, 41(7):1023-31.

6. Abdullah Y. Consanguineous marriage and its affect on spousal concordance among the "Al-Kandari" in Kuwait [Dissertation]. Ohio, The Ohio State University, 1999.

7. Al-Kandari Y, Poirier F. Modernization and family structure in Kuwait. The educational journal, 2001, 60(15):225-39.

8. Ruudi N. Population policies vary in Middle East. Population today, 1993, 21(4):3-10.

9. Annual statistical abstract. Kuwait, Ministry of Planning, Statistic and Information Sector, 2000.

10. Van Dussen R, Zill N. Basic background items for US household surveys. Washington DC, Social Science Research Council, 1975.

11. Hern WM. Cultural change, polygyny, and fertility among the Shipibo of the Peruvian Amazon. South American Indian studies, 1994, (4):77-86.

12. Greenspan A. Age at marriage is rising for Asian women and men, according to new data. Asia-Pacific population \& policy, 1992, (22):1-4.

13. Reher DS, Iriso-Napal PL. Marital fertility and its determinants in rural and in Urban Spain, 1887-1930. Population studies, 1989, 43(3):405-27.

14. Hollos M, Larsen U. Fertility differentials among the ljo in southern Nigeria: Does urban residence make a difference? Social science \& medicine, 1992, 35(9):1199210.

15. Hoque MN, Murdock SH. Socioeconomic development, status of women, family planning, and fertility in Bangladesh: a district level analysis. Social biology, 1997, 44(3-4):179-97.

16. Uchudi JM.. Spouses' socioeconomic characteristics and fertility differences in sub-Saharan Africa: does spouse's education matter? Journal of biosocial science, 2001, 33(4):481-502.

17. Hamilton BE, Sutton PD, Ventura SJ. Revised birth and fertility rates for the 1990s and new rates for Hispanic populations, 2000 and 2001: United States. National vital statistics reports, 2003, 51(12):1-94.

18. Trovato F. Canadian ethnic fertility. Social focus, 1981, 14(1):57-74.

19. Mosher WD, Bachrach CA. Understanding US fertility: continuity and change in the National Survey of Family Growth, 1988-1995. Family planning perspectives, 1996, 28(1):4-12.

20. Sueyoshi S, Ohtsuka R. Effects of polygyny and consanguinity on high fertility in the rural Arab population in south Jordan. Journal of biosocial science, 2003 , 35(4):513-26

21. Yasim Naidu JM, Mascie-Taylor CG. Consanguinity and its relationship to differential fertility and mortality in the Kotia: a tribal population of Andhra Pradesh, India. Journal of biosocial science, 1997, 29(2):171-80.

المجلة الصحية لشرق المتو سط، منظمة الصحة العالمية، المجلد الثالث عشر، العدد ب، V... 